\title{
Financial Toxicity and Non-small Cell Lung Cancer Treatment: The Optimization in the Choice of Immune Check Point Inhibitors*
}

\author{
JACOPO GIULIANI and ANDREA BONETTI
}

\author{
Department of Oncology, Mater Salutis Hospital, Legnago, Italy
}

\begin{abstract}
Background/Aim: Immune check point inhibitors (ICIs) are changing cancer treatment in several malignancies, including non-small cell lung cancer (NSCLC). The introduction of these active new agents is associated with a relevant increase of costs and it is, therefore, important to create a balance between the costs of treatment and the added value represented by the improvement of the clinical parameters of interest such as overall survival (OS). This analysis was conducted to assess the pharmacological costs of first- and second-line treatments with ICIs (pembrolizumab, nivolumab and atezolizumab) for metastatic NSCLC. Materials and Methods: The present evaluation was restricted to phase III randomized controlled trials (RCTs). We calculated the pharmacological costs necessary to get the benefit in OS. Results: Six phase III RCTs were evaluated. Concerning firstline, the lowest cost per month of OS-gain was associated with the use of pembrolizumab at 2,734 €. Concerning second-line, the lowest cost per month of OS-gain was associated with the use of atezolizumab at 3,724 $€$. Conclusion: Pembrolizumab and atezolizumab are cost-effective in both first and secondline treatment for metastatic NSCLC, respectively.
\end{abstract}

Immune check point inhibitors (ICIs) are changing cancer treatment in several malignancies, including squamous and non-squamous non-small cell lung cancer (NSCLC) (1). In particular, the introduction of ICIs, such as pembrolizumab, nivolumab and atezolizumab, in first and second-line treatment

*Presented at the 40th EORTC-PAMM Winter Meeting, February 2019, Verona, Italy.

Both Authors contributed equally to this study.

Correspondence to: Jacopo Giuliani, Department of Oncology, Mater Salutis Hospital, Az. ULSS 9 Scaligera, Via Gianella 1, 37045 Legnago (VR), Italy. Tel: +39 0442622364, Fax: +39 0442622469, e-mail: jacopo.giuliani@aulss9.veneto.it

Key Words: NSCLC, first-line, second-line, phase III RCTs, pembrolizumab, nivolumab, atezolizumab, cost of drugs. of metastatic NSCLC with no targetable alterations, such as epidermal growth factor receptor (EGFR)-activating mutations, anaplastic lymphoma kinase (ALK)-translocations or the protooncogene tyrosine-protein kinase ROS1 translocation/rearrangements, have demostrated improvements in survival relative to standard chemotherapy (2). In light of the relevant expenses of these new pharmacological interventions it might be interesting to examine the balance between the cost of ICIs and the added value represented by the improvement of the clinical parameters of interest, such as overall survival (OS). The present analysis was conducted to assess the pharmacological costs of first and second-line treatments with ICIs (pembrolizumab, nivolumab and atezolizumab) for metastatic NSCLC.

\section{Materials and Methods}

The present evaluation was restricted to phase III randomized controlled trials (RCTs) in first and second-line treatments with pembrolizumab, nivolumab and atezolizumab for metastatic NSCLC without EGFR-activating mutations, ALK-translocations or ROS1 translocation/re-arrangements. We calculated differences in OS (expressed in months) between the different arms of each trial. Then, we calculated the pharmacological costs necessary to get the benefit in OS, for each trial. Calculations were based on an "ideal patient" (BSA $1.8 \mathrm{~m}^{2}$, weight $70 \mathrm{Kg}$ ). The dosage of drugs was considered according to what is reported in each RCT.

The costs of drugs at the Pharmacy of our Hospital are expressed in Euros $(€)$. Currently, no drug dosage is available per single vial in our Country. We assumed the following costs: i) nivolumab at $240 \mathrm{mg}$ flat dose every 2 weeks (Q2W), with each administration at 3,225 euros (each medication vial is $100 \mathrm{mg}$ and the cost of each vial was $1,075 €$, so 3 vials were used for each administration), ii) docetaxel at $18 €$ for the cost of 1 cycle, iii) pembrolizumab at $2,056.08 €$ for $100 \mathrm{mg}$ [in the calculation of costs only pembrolizumab at $2 \mathrm{mg} / \mathrm{Kg}$ was considered (single dose recorded in the data sheet)], and iv) atezolizumab at 3,139.08 $€$ for $1200 \mathrm{mg}$. We have also applied the ESMO Magnitude of Clinical Benefit Scale (ESMO-MCBS) (3) to the above pivotal phase III RCTs, with adjustments (upgrade or down-grade) planned based on quality of life (QoL) or grade 3-4 toxicities impacting daily well-being (3). The last available update of each trial was considered as the original source. The deadline for trial publication and/or presentation was 
January 31th, 2019. All data were reviewed by 2 investigators (JG and $\mathrm{AB}$ ) and separately computed by 2 investigators (JG and $\mathrm{AB}$ ).

\section{Results}

Our analysis evaluated 6 phase III RCTs (2 RCTs in first-line and 4 RCTs in second-line) (4-10), including 3,545 patients. Regarding first-line treatment (Table I), progression free survival (PFS) ranged from 4.2 months of nivolumab in the CheckMate026 trial (6) to 10.3 months of pembrolizumab in the KEYNOTE-024 trial (4). OS was 14.4 months of nivolumab in the CheckMate026 trial (6) and 30.0 months of pembrolizumab in the OS update of KEYNOTE-024 trial (5). ESMO-MCBS reached high score (grade 5) for the KEYNOTE-024 trial $(4,5)$, while nivolumab otained low score (grade 1) ESMO-MCBS in the CheckMate026 trial (6). Concerning the second-line treatments (Table II), OS ranged from 2.3 months of nivolumab in the CheckMate 057 (8) to 4.2 months of docetaxel in the same trial (8), and from 6 months of docetaxel in the CheckMate 017 (7) to 13.8 months of atezolizumab in the OAK (10). ESMO-MCBS reached high score (grade 5) for the CheckMate 017 (7) trial, KEYNOTE010 (9) trial and OAK trial (10), while CheckMate 057 (8) reached grade 4 in the ESMO-MCBS. Concerning the firstline treatment, the most relevant increase of costs were associated with the use of nivolumab, with $18,813 €$ per month of OS-gain, while the lowest cost per month of OS-gain was associated with the use of pembrolizumab with $2,734 €$ (Table I). Concerning the second-line treatment, the most relevant increase of costs was associated with pembrolizumab with $15,122 €$ per month of OS-gain, while the lowest cost per month of OS-gain was associated with the use of atezolizumab with $3,724 €$ (Table II).

\section{Discussion}

In this study we reviewed phase III RCTs that reported the effect of first and second-line treatments with the ICIs, pembrolizumab, nivolumab and atezolizumab, for metastatic NSCLC, to find out the incremental costs necessary to get the benefit in OS, for each trial. We have limited our evaluation to phase III RCTs for different reasons. First, phase II trials are plagued by patient's selection biases and this reduces the possibility to define "credible" measures of efficacy, such as PFS and OS. Second, RCTs are needed to allow comparison of efficacy. So, data showed that the pharmacological costs were influenced by two main factors: i) the efficacy of the therapies (strictly associated with the patient's inclusions criteria) and ii) the price of drugs used. Combining the costs of therapy with the measure of efficacy represented by OS, we got the costs for obtaining the advantage in OS. The use of atezolizumab was associated with the lowest cost per month OS-gain in first-line for metastatic NSCLC $(2,734 €)$. In second-line treatment for metastatic NSCLC, atezolizumab had the lowest cost per month of OS-gain $(3,724 €)$.

Our review has several limitations, first of which involves the cross-trial comparisons. Moreover, we have considered only the direct costs, but there are other important cost elements that are not considered here (e.g. outpatient/inpatient administration costs or treatment-related adverse event costs or health-related quality of life between the different first-line treatments). In fact, the data we have reported are not a real cost-effectiveness analysis (that would imply not only direct medical costs, but also indirect medical costs), but an analysis of pharmacological costs. Moreover, using PFS and OS as part of the analysis is unconventional but raises interesting issues. We decided to consider OS because PFS on its own would likely underestimate the life-years saved (11-13). In addition, ESMO-MCBS considers the QoL in the definition of the clinical benefits of each RCT, and adjustments (upgrade or down-grade) are planned based on QoL or grade 3-4 toxicities impacting daily well-being (3).

The annual costs of ICIs treatment are in line with those reported by Azimi and Welch (14), that found a favored implementing intervention for thresholds of less than $\$$ 61,500 per life-year gained, only for pembrolizumab in firstline (\$28,779) and atezolizumab in second-line $(\$ 39,200)$ treatment. At current prices, nivolumab cannot be considered cost-effective for metastatic NSCLC, both in first (negative results of CheckMate026 (6)) and second-line treatments for both non-squamous $(\$ 72,474)$ and squamous $(\$ 84,695)$ metastatic NSCLC. The cost of nivolumab would be economically sustainable with a dosage at $3 \mathrm{mg}$ pro $\mathrm{Kg}$ [currently nivolumab is approved at $240 \mathrm{mg}$ flat dose Q2W, based on data of comparable efficacy and safety towards nivolumab at $3 \mathrm{mg} / \mathrm{kg}$ Q2W schedule $(15,16)]$, with 4,809 $€$ and 5,623 $€$ per month of OS-gain in non-squamous (8) and squamous NSCLC (7), respectively, and with \$50,621 and $\$ 59,189$ of annual perspective, respectively. Concerning pembrolizumab, recently a flat dose of $200 \mathrm{mg}$ was approved also for second-line treatment for NSCLC (17). There are no differences in terms of costs per month OS-gain also for 200 $\mathrm{mg}$ flat dose $(15,122 €)$ versus pro-Kg dosage.

The pharmacological costs are transferred to the Italian reality and, more generally, to Europe (free movement of patients and goods). The idea is to emphasize not only on the cost topic, but also on the method, which is to combine the pharmacological costs of drugs with the measures of efficacy (OS).

However, to our knowledge, this is the first time an analysis of the pharmacological costs of regimens in first and second-line treatments with ICIs for metastatic NSCLC is integrated with OS and clinical benefit.

Combining pharmacological costs of drugs with the measure of efficacy represented by OS, pembrolizumab and atezolizumab are cost-effective in first and second-line 


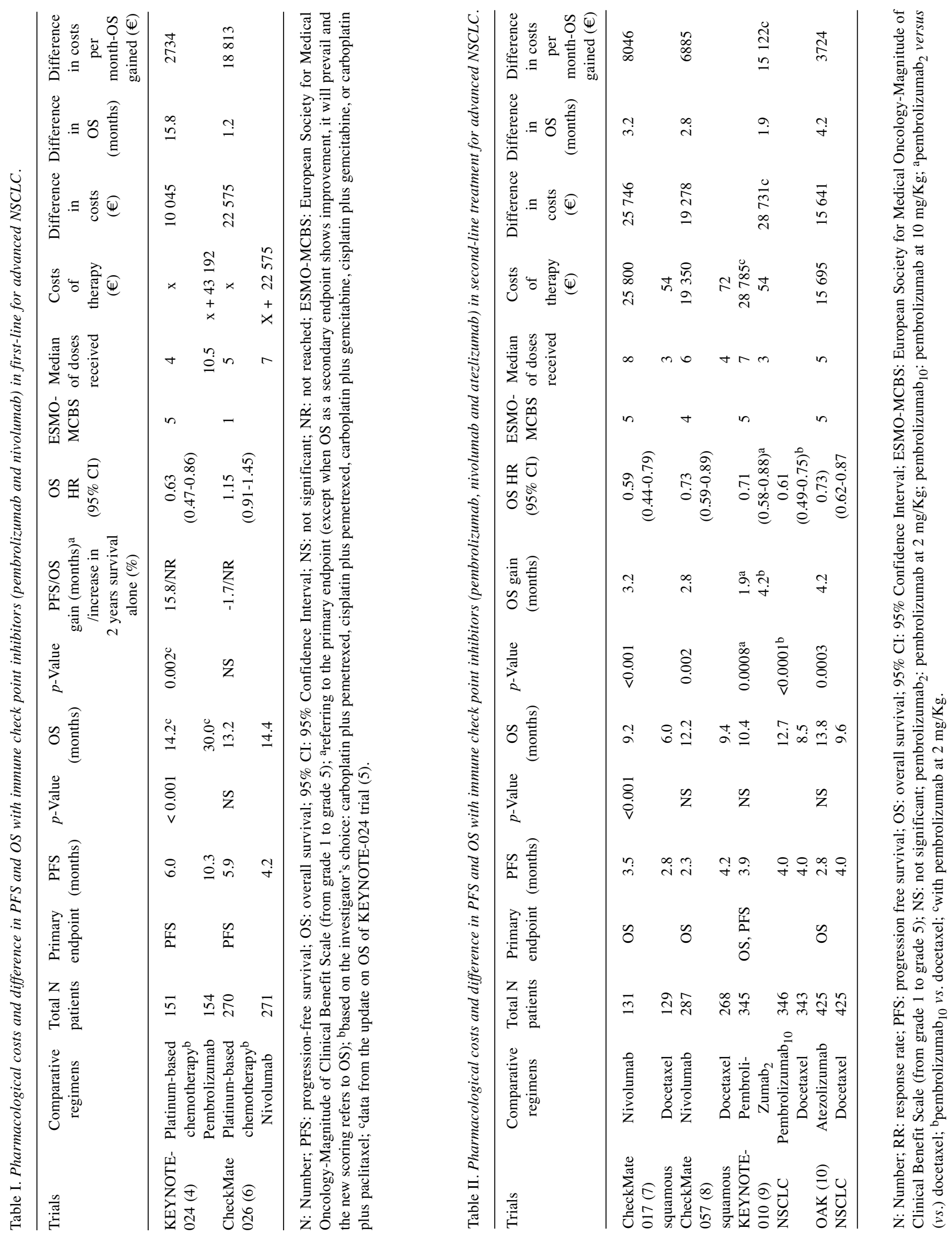


treatment for metastatic NSCLC, respectively. The price of newly registered oncologic drugs is continuously increasing, which poses a serious threat to the sustainability of the National Health Systems, especially in Countries in which the public control and oversight over the prices is limited. Medical Oncologists and the society as a whole are becoming more and more concerned with the issues of the costs of the cure of cancer patients and are able to bring attention to the "just price" of new treatments that must reflect the reality of their true benefits and societal and personal costs (18).

\section{Conflicts of Interest}

The Authors have no conflicts of interest to declare.

\section{Authors' Contributions}

JG and $\mathrm{AB}$ contributed equally to the conception and design of the study, acquisition, analysis and interpretation of data, drafting the article and revising it critically for important intellectual content, as well as for its final approval to be published.

\section{Acknowledgements}

No funds were received to support this article.

\section{References}

1 Clarke JM, George DJ, Lisi S and Salama AKS: Immune Checkpoint Blockade: The New Frontier in Cancer Treatment Target Oncol 13(1): 1-20, 2018. PMID: 29441437. DOI: 10.1007/s11523-017-0549-7

2 Assi HI, Kamphorst AO, Moukalled NM and Ramalingam SS: Immune checkpoint inhibitors in advanced non-small cell lung cancer. Cancer 124(2): 248-261, 2018. PMID: 29211297. DOI: 10.1002/cncr.31105

3 Cherny NI, Sullivan R, Dafni U, Kerst JM, Sobrero A, Zielinski $\mathrm{C}$, de Vries EG and Piccart MJ: A standardised, generic, validated approach to stratify the magnitude of clinical benefit that can be anticipated from anti-cancer therapies: the European Society for Medical Oncology Magnitude of Clinical Benefit Scale (ESMO-MCBS). Ann Oncol 26(8): 1547-1573, 2015. PMID: 26026162. DOI: 10.1093/annonc/mdv249

4 Reck M, Rodríguez-Abreu D, Robinson AG, Hui R, Csőszi T, Fülöp A, Gottfried M, Peled N, Tafreshi A, Cuffe S, O'Brien M, Rao S, Hotta K, Leiby MA, Lubiniecki GM, Shentu Y, Rangwala R and Brahmer JR; KEYNOTE-024 Investigators: Pembrolizumab versus chemotherapy for PD-L1-positive nonsmall-cell lung cancer. N Engl J Med 375(19): 1823-1833, 2016. PMID: 27718847. DOI: 10.1056/NEJMoa1606774

5 Reck M, Rodríguez-Abreu D, Robinson AG, Hui R, Csőszi T, Fülöp A, Gottfried M, Peled N, Tafreshi A, Cuffe S, O'Brien M, Rao S, Hotta K, Vandormael K, Riccio A, Yang J, Pietanza MC and Brahmer JR. Updated Analysis of KEYNOTE-024: Pembrolizumab versus platinum-based chemotherapy for advanced non-small-cell lung cancer with PD-L1 tumor proportion score of $50 \%$ or greater. J Clin Oncol 37(7): 537-546, 2019. PMID: 30620668. DOI: 10.1200/JCO.18.00149

6 Carbone DP, Reck M, Paz-Ares L, Creelan B, Horn L, Steins M, Felip E, van den Heuvel MM, Ciuleanu TE, Badin F, Ready N, Hiltermann TJN, Nair S, Juergens R, Peters S, Minenza E, Wrangle JM, Rodriguez-Abreu D, Borghaei H, Blumenschein GR Jr., Villaruz LC, Havel L, Krejci J, Corral Jaime J, Chang $\mathrm{H}$, Geese WJ, Bhagavatheeswaran P, Chen AC and Socinski MA; CheckMate 026 Investigators: First-Line nivolumab in stage IV or recurrent non-small-cell lung cancer. N Engl J Med 376(25): 2415-2426, 2017. PMID: 28636851. DOI: 10.1056/NEJMoa1613493

7 Brahmer J, Reckamp KL, Baas P, Crinò L, Eberhardt WE, Poddubskaya E, Antonia S, Pluzanski A, Vokes EE, Holgado E, Waterhouse D, Ready N, Gainor J, Arén Frontera O, Havel L, Steins M, Garassino MC, Aerts JG, Domine M, Paz-Ares L, Reck M, Baudelet C, Harbison CT, Lestini B and Spigel DR: Nivolumab versus docetaxel in advanced squamous-cell nonsmall-cell lung cancer. N Engl J Med 373(2): 123-135, 2015. PMID: 26028407. DOI: 10.1056/NEJMoa1504627

8 Borghaei H, Paz-Ares L, Horn L, Spigel DR, Steins M, Ready NE, Chow LQ, Vokes EE, Felip E, Holgado E, Barlesi F, Kohlhäufl M, Arrieta $\mathrm{O}$, Burgio MA, Fayette J, Lena H, Poddubskaya E, Gerber DE, Gettinger SN, Rudin CM, Rizvi N, Crinò L, Blumenschein GR Jr., Antonia SJ, Dorange C, Harbison $\mathrm{CT}$, Graf Finckenstein $\mathrm{F}$ and Brahmer JR: Nivolumab versus docetaxel in advanced nonsquamous non-small-cell lung cancer. N Engl J Med 373(17): 1627-1639, 2015. PMID: 26412456. DOI: $10.1056 /$ NEJMoa1507643

9 Herbst RS, Baas P, Kim DW, Felip E, Pérez-Gracia JL, Han JY, Molina J, Kim JH, Arvis CD, Ahn MJ, Majem M, Fidler MJ, de Castro G Jr, Garrido M, Lubiniecki GM, Shentu Y, Im E, Dolled-Filhart $M$ and Garon EB: Pembrolizumab versus docetaxel for previously treated, PD-L1-positive, advanced nonsmall-cell lung cancer (KEYNOTE-010): a randomised controlled trial. Lancet 387(10027): 1540-1450, 2016. PMID: 26712084. DOI: 10.1016/S0140-6736(15)01281-7

10 Rittmeyer A, Barlesi F, Waterkamp D, Park K, Ciardiello F, von Pawel J, Gadgeel SM, Hida T, Kowalski DM, Dols MC, Cortinovis DL, Leach J, Polikoff J, Barrios C, Kabbinavar F, Frontera OA, De Marinis F, Turna H, Lee JS, Ballinger M, Kowanetz M, He P, Chen DS, Sandler A and Gandara DR; OAK Study Group: Atezolizumab versus docetaxel in patients with previously treated non-small-cell lung cancer (OAK): a phase 3, open-label, multicentre randomised controlled trial. Lancet 389(10066): 255-265, 2017. PMID: 27979383. DOI: 10.1016/ S0140-6736(16)32517-X

11 Olchanski N, Zhong Y, Cohen JT, Saret C, Bala M and Neumann PJ: The peculiar economics of life-extending therapies: a review of costing methods in health economic evaluations in oncology. Expert Rev Pharmacoecon Outcomes Res 15(6): 931-940, 2015. PMID: 26478989. DOI: 10.1586/14737167.2015.1102633

12 Cohn DE, Kim KH, Resnick KE, O'Malley DM and Straughn JM Jr: At what cost does a potential survival advantage of bevacizumab make sense for the primary treatment of ovarian cancer? A cost-effectiveness analysis. J Clin Oncol 29(10): 12471251, 2011. PMID: 21383297. DOI: 10.1200/JCO.2010.32.1075

13 Shi Q, de Gramont A, Grothey A, Zalcberg J, Chibaudel B, Schmoll HJ, Seymour MT, Adams R, Saltz L, Goldberg RM,Punt CJ, Douillard JY, Hoff PM, Hecht JR, Hurwitz H, 
Díaz-Rubio E, Porschen R, Tebbutt NC, Fuchs C, Souglakos J,Falcone A, Tournigand C, Kabbinavar FF, Heinemann V, Van Cutsem E, Bokemeyer C, Buyse M and Sargent DJ: Individual patient data analysis of progression-free survival versus overall survival as a first-line end point for metastatic colorectal cancer in modern randomized trials: findings from the analysis and research in cancers of the digestive system database. J Clin Oncol 33(1): 22-28, 2015. PMID: 25385741. DOI: 10.1200/ JCO .2014.56.5887

14 Azimi NA and Welch HG: The effectiveness of costeffectiveness analysis in containing costs. J Gen Intern Med (13810): 664-669, 1998. PMID: 9798812. DOI: 10.1046/j.15251497.1998.00201.x

15 Zhao X, Suryawanshi S, Hruska M, Feng Y, Wang X, Shen J, Vezina HE, McHenry MB, Waxman IM, Achanta A, Bello A, Roy A and Agrawal S: Assessment of nivolumab benefit-risk profile of a $240-\mathrm{mg}$ flat dose relative to a $3-\mathrm{mg} / \mathrm{kg}$ dosing regimen in patients with advanced tumors. Ann Oncol 28(8): 2002-2008, 2017. PMID: 28520840. DOI: 10.1093/annonc/ mdx235
16 Opdivo Prescribing Information. Opdivo U.S. Product Information. Last updated: March 2018. Princeton, NJ: BristolMyers Squibb Company.

17 Freshwater T, Kondic A, Ahamadi M, Li CH, de Greef R, de Alwis D and Stone JA: Evaluation of dosing strategy for pembrolizumab for oncology indications. J Immunother Cancer 5: 43, 2017. PMID: 28515943. DOI: 10.1186/s40425-017-0242-5

18 Giuliani $\mathrm{J}$ and Bonetti A: FOLFIRINOX is a cost-effective combination chemotherapy in first-line for advanced pancreatic cancer. Pancreatology 19(2): 325-330, 2019. PMID: 30704852. DOI: $10.1016 /$ j.pan.2019.01.014

Received March 31, 2019

Revised May 25, 2019

Accepted May 28, 2019 